\title{
PENGARUH PENGISIAN EKSPEDISI TERHADAP EFISIENSI PENDISTRIBUSIAN REKAM MEDIS RAWAT JALAN DI RSKIA BANDUNG
}

\author{
Yayu Siti Solihah ${ }^{1 *}$, Irda Sari \\ Politeknik Piksi Ganesha ${ }^{1,2}$ \\ piksi.yayu.18303080@gmail.com ${ }^{1 *}$, irdasari13@gmail.com ${ }^{2}$
}

Received: 28-07-2021

Revised : 18-10-2021

Accepted: $20-10-2021$

\begin{abstract}
Abstrak
Latar Belakang: Beberarapa petugas yang tidak mengisi ekpedisi meskipun sudah berbasis computer untuk sarana prasarana peminjaman berkas rekam medis pasien, jadi pada saat unit lain akan meminjam berkas rekam medis, berkas rekam medis tersebut tidak ada di rak penyimpanan maupun di ekspedisi SIMRS, hal itu yang membuat bagian distribusi kesulitan mencari berkas rekam medis pasien yang akan di antarkan ke peminjam rekam medis.
\end{abstract}

Tujuan: Penelitian ini dilakukan bertujuan untuk mengetahui seberapa besar pengaruh pengisian ekspedisi peminjaman terhadap proses pendistribusian rekam medis.

Metode: Penelitian ini menggunakan metode pendekatan kuantitatif yaitu dengan cara menjawab beberapa pertanyaan/pernyataan peneliti, teknik yang dilakukan ialah dengan cara uji validitas, reliabilitas, regresi sederhana dan korelasi pearson 5\% menggunakan bantuan SPSS, sedangkan tehnik pengumpulan data dengan cara angket (kuesioner) dengan penilaian likert 1-5.

Hasil: Berdasarkan hasil penelitian setelah dilakukan uji korelasi pearson 5\% ternyata hasil nya memiliki korelasi atau hubungan yang lemah (korelasi lemah) karena nilai korelasi pearson nya ialah $0,40=$ korelasi lemah, dapat disimpulkan bahwa variable $\mathrm{X}$ tidak berpengaruh besar pada variable $\mathrm{Y}$.

Kesimpulan: Setiap pernyataan/pertanyaan yang terdapat pada kuesioner/angket di uji validitas menggunakan SPSS 17.0 dinyatakan valid begitupun dengan reliabilitas atau kekonsistenan, tetapi pada saat diujikan regresi ternyata dapat dihasilkan hubungan antara variable X (ekspedisi) dan variable $\mathrm{Y}$ (distribusi) tidak berpengaruh namun memiliki hubungan yang positif.

Kata kunci: rekam medis; ekspedisi; distribusi.

\begin{abstract}
Background: Some officers did not fill out the expedition even though it was computer-based for the infrastructure for borrowing patient medical record files, so when other units were going to borrow medical record files, the medical record files were not on the storage rack or on SIMRS
\end{abstract}




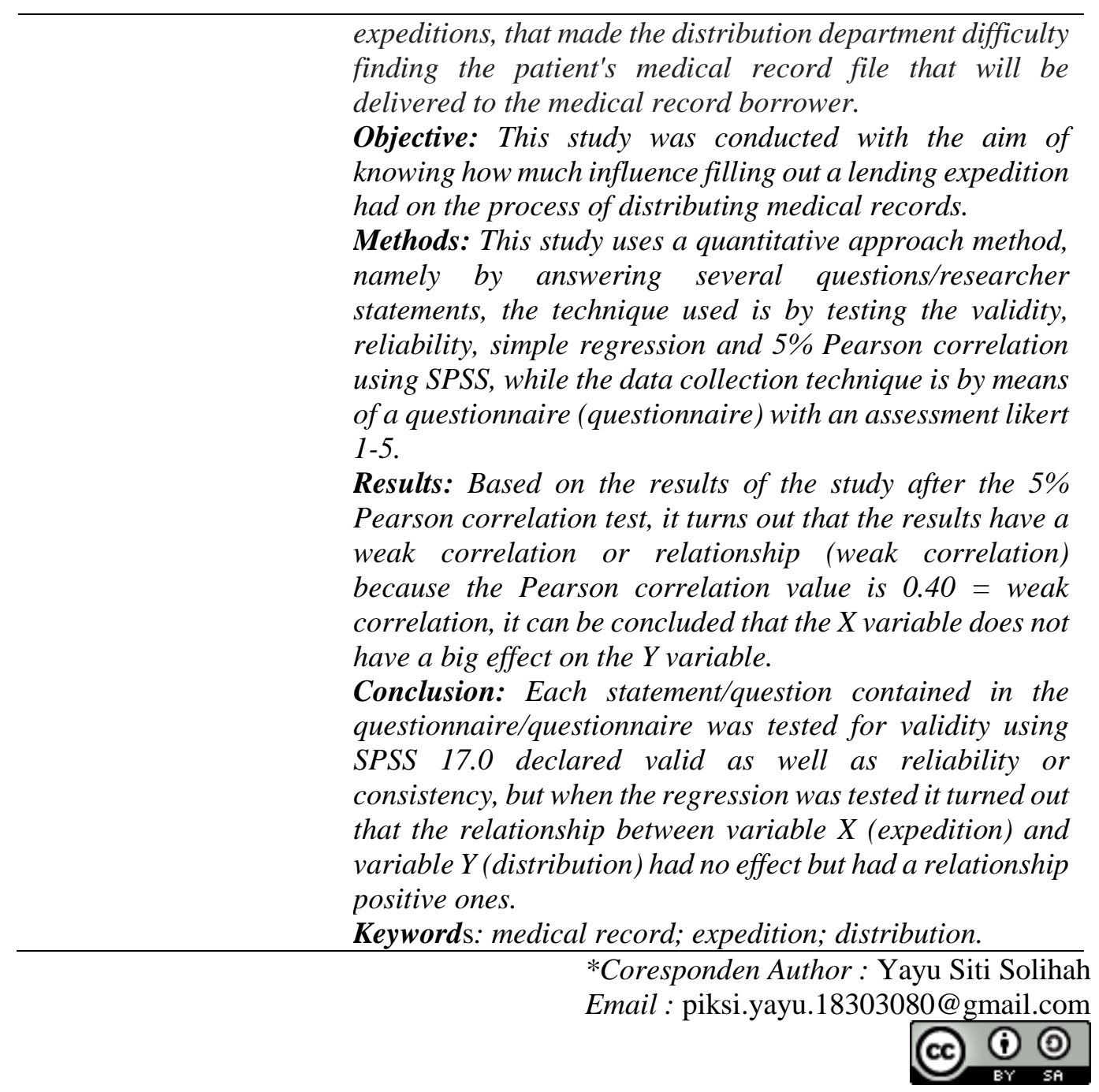

\section{PENDAHULUAN}

Rumah Sakit adalah institusi pelayanan kesehatan yang menyelenggarakan pelayanan kesehatan perorangan secara paripurna yang menyediakan pelayanan rawat inap, rawat jalan, dan gawat darurat (Menkes, 2010). Rekam medis merupakan dokumen yang berisi catatan terkait dengan data administrasi dan data klinis pasien selama memperoleh pelayanan kesehatan. Rekam medis memiliki arti suatu dokumen yang berisikan catatan dan dokumen tentang identitas pasien, pemeriksaan, pengobatan, tindakan, dan pelayanan lain yang telah diberikan kepada pasien (K. RI, 2008). Setiap dokumen yang keluar dan masuk dari unit filing harus dicatat dibuku ekspedisi dan tracer (Jamil et al., 2020).

Rekam medis merupakan dokumen yang berisi catatan terkait dengan data administrasi dan data klinis pasien selama memperoleh pelayanan kesehatan. Rekam medis memiliki arti suatu dokumen yang berisikan catatan dan dokumen tentang identitas pasien, pemeriksaan, pengobatan, tindakan, dan pelayanan lain yang telah diberikan kepada pasien. Rekam medik yang lengkap adalah rekam medik yang telah di isi lengkap oleh dokter dalam waktu kurang dari $\leq 24$ jam setelah selesai pelayanan rawat jalan atau setelah pasien rawat inap diputuskan untuk pulang, yang meliputi identitas pasien, anamnesis, rencana asuhan, pelaksanaan asuhan, tidak lanjut dan resume medis (D. RI, 2008). Ketersediaan data dan informasi yang lengkap tersebut dapat menjadi parameter dalam menilai mutu pelayanan kesehatan. 
Ekspedisi di Rumah Sakit Khusus Ibu dan Anak Kota Bandung digunakan untuk peminjaman dan pengembalian dokumen rekam medis yang meliputi tanggal pinjam, unit yang meminjam, nama petugas yang meminjam, jumlah rekam medis keluar/di pinjam, dan jumlah rekam medis masuk yang akan disimpan di unit pendistribusian dan penyimpanan (Arif, 2018).

Pendistribusian adalah proses pengiriman berkas rekam medis ke poliklinik yang dituju untuk proses pelayanan kesehatan. Pendistribusian berkas rekam medis yang baik adalah pendistribusian berkas rekam medis yang cepat, tepat dan efisien. Jika waktu dalam pendistribusian rekam medis lama, maka akan menghambat pelayanan kesehatan yang akan diberikan dokter kepada pasien, karena dokter tidak dapat memberikan pelayanan kesehatan kepada pasien tanpa adanya berkas rekam medis pasien tersebut (Putri \& Putra, 2018).

Rumah Sakit Khusus Ibu dan Anak Kota Bandung khususnya pada bagian distribusi bahwa dalam penyediaan dan pengiriman rekam medis untuk sampai ke poliklinik maupun ke ruang rawat inap sering kali mengalami keterlambatan, menurut hasil dari Sistem Informasi Manajemen Rumah Sakit (SIMRS), berkas yang di distribusi tidak $100 \%$ sesuai dengan standar waktu pengiriman rekam medis yaitu $<30$ menit, sistem pendistribusian yang dilakukan oleh petugas Rumah Sakit Khusus Ibu dan Anak Kota Bandung masih dengan cara manual yaitu petugas membawa berkas dengan menggunakan tangan kosong maupun trolli dan lift khusus pegawai ketika melakukan pendistribusian ke lantai atas, sehingga cukup memakan waktu untuk memenuhi standar pelayanan minimal (SPM) (Pratiwi, 2021).

Berkas rekam medis dikatakan salah letak atau hilang (missfile) apabila berkas tersebut dibutuhkan akan tetapi pada rak penyimpanan berkas tersebut tidak tersedia atau tidak ada. Hal ini mungkin dapat terjadi karena tidak tercatatnya berkas yang keluar pada buku ekspedisi dan tidak adanya alat berupa tracer sehingga berkas tersebut hilang atau salah letak (Salawiyah et al., 2021). Missfile berkas juga dapat menyebabkan duplikasi berkas rekam medis dimana hal ini sejalan dengan penelitian yang dilakukan oleh (Wati \& Nuraini, 2019) yang menyatakan bahwa missfile berkas rekam medis dapat menyebabkan duplikasi berkas rekam medis dimana satu pasien memiliki dua nomor rekam medis karena hal tersebut menyebabkan tidak tercapainya hasil pemeriksaan pasien yang berkesinambungan karena terpisahnya penempatan catatan riwayat pasien sebelumnya.

Hal itu salah satu penyebab yang membuat petugas bagian pendistribusian kebingungan mencari berkas tersebut dan memakan waktu yang lama untuk pendistribusian berkas pasien ke poliklinik maupun rawat inap, serta memengaruhi standar pelayanan minimal, yang terkadang jika pada saat sangat dibutuhkan berkas rekam medis pasien seperti pada saat jika pasien sedang instalasi gawat darurat, terkadang petugas membuat rekam medis baru, dikarenakan rekam medis pasien yang lama tidak ada di rak penyimpanan dan sulit dicari di ekspedisi SIMRS, dan pada saat rekam medis lama pasien ketemu terjadi duplikasi rekam medis pasien (Mun et al., 2019).

Maka dalam penelitian ini penulis tertarik untuk menyusun laporan berupa jurnal dengan judul. "Pengaruh Pengisian Ekspedisi Terhadap Efisiensi Proses Pendistribusian Rekam Medis Rawat Inap dan Rawat Jalan di Rumah Sakit Khusus Ibu dan Anak Bandung".

\section{METODE PENELITIAN}

Metode penelitian ini dilakukan dengan pendekatan kuantitatif (Quantitative Research) yaitu dengan cara menjawab beberapa pertanyaan penelitian. Dalam menyusun instrument atau pengumpul data, variabel-variabel yang menjadi acuan utama peneliti dalam menyusun angket (kuesioner) terdiri atas angket (kuesioner) tentang pengisian ekspedisi dan distribusi. cara-cara yang digunakan dalam analisa data adalah uji korelasi 
pearson dan uji regresi linier. Lokasi yang digunakan dalam penelitian ini yaitu Rumah Sakit Khusus Ibu dan Anak Kota Bandung. Selanjutnya yang menjadi populasi dalam penelitian ini adalah seluruh pegawai rekam medis.

Sampel adalah sebagian dari jumlah dan karakteristik yang dimiliki oleh populasi tersebut (Sugiyono, 2013). Berdasarkan hal tersebut peneliti menjadikan seluruh populasi sebagai sampel penelitian. Dengan demikian peneliti meyakini bahwa kuisioner yang diberikan kepada responden dapat diisi sesuai dengan kenyataan yang ada di Rumah Sakit Khusus Ibu dan Anak Kota Bandung.

Penelitian ini menggunakan 21 orang/petugas rekam medis di Rumah Sakit Khusus Ibu dan Anak Kota Bandung sebagai sampel penelitian. Analisis data terhadap pengaruh pengisian ekspedisi terhadap distribusi rekam medis di Rumah Sakit Khusus Ibu dan Anak Kota Bandung dilakukan dengan bantuan software statistik komputer SPSS. Analisis yang dilakukan adalah uji validitas data, uji realiabilitas dan analisis uji korelasi pearson dan regresi linear.

\section{HASIL DAN PEMBAHASAN}

\section{A. Hasil Penelitian}

Uji Validitas

Tabel 1. Hasil Validitas Dengan Menggunakan R Hitung > R Tabel

\begin{tabular}{cccc}
\hline Pernyataan & R hitung & R tabel & keterangan \\
\hline P01 & 0,513 & 0,433 & Valid \\
\hline P02 & 0,711 & 0,433 & Valid \\
\hline P03 & 0,475 & 0,433 & Valid \\
\hline P04 & 0,610 & 0,433 & Valid \\
\hline P05 & 0,456 & 0,433 & Valid \\
\hline P06 & 0,549 & 0,433 & Valid \\
\hline P07 & 0,481 & 0,433 & Valid \\
\hline P08 & 0,461 & 0,433 & Valid \\
\hline P09 & 0,658 & 0,433 & Valid \\
\hline P10 & 0,496 & 0,433 & Valid \\
\hline P11 & 0,607 & 0,433 & Valid \\
\hline P12 & 0,583 & 0,433 & Valid \\
\hline P13 & 0,554 & 0,433 & Valid \\
\hline P14 & 0,464 & 0,433 & Valid
\end{tabular}

Dasar prngambilan uji validitas, dengan perbandingan $r$ hitung dan $r$ tabel :

1. jika nilai $r$ hitung $>r$ tabel $=$ valid

2. jika nilai $r$ hitung $<\mathrm{r}$ tabel $=$ tidak valid

Dapat dilihat pada tabel 1 hasil uji validitas yang telah dilakukan oleh peneliti, dari tabel tersebut peneliti memberikan pertanyaan/pernyataan sebanyak 15 butir kepada 21 responden, dengan hasil > dari 0,433, maka dari itu hasil uji validitas yang dilakukan peneliti menggunakan $r$ hitung dan $r$ tabel disimpulkan valid.

\section{Uji Validitas}


Tabel 2. hasil validitas dengan melihat nilai signifikansi

\begin{tabular}{cccl}
\hline Pernyataan & Signifikansi penelitian & Signifikansi statistik & keterangan \\
\hline P01 & 0,01 & 0,05 & Valid \\
\hline P02 & 0,00 & 0,05 & Valid \\
\hline P03 & 0,03 & 0,05 & Valid \\
\hline P04 & 0,00 & 0,05 & Valid \\
\hline P05 & 0,03 & 0,05 & Valid \\
\hline P06 & 0,01 & 0,05 & Valid \\
\hline P07 & 0,02 & 0,05 & Valid \\
\hline P08 & 0,03 & 0,05 & Valid \\
\hline P09 & 0,00 & 0,05 & Valid \\
\hline P10 & 0,02 & 0,05 & Valid \\
\hline P11 & 0,00 & 0,05 & Valid \\
\hline P12 & 0,00 & 0,05 & Valid \\
\hline P13 & 0,00 & 0,05 & Valid \\
\hline P14 & 0,03 & 0,05 & Valid \\
\hline P15 & 0,03 & 0,05 & Valid
\end{tabular}

Jika melihat nilai signifikansi (sign) :

1. jika nilai signifikansi $<0,05=$ valid

2. jika nilai signifikansi $>0,05=$ tidak valid

Pada tabel 2 hasil uji validitas menggunakan signifikansi yang dilakukan oleh peneliti dengan 15 butir pertanyaan/pernyataan yang di berika kepada 21 responden, dengan hasil $<0,05$, maka dari itu hasil uji validitas menggunakan signifikansi yang dilakukan oleh peneliti dapat disimpulkan valid.

\section{Uji Reliabel}

Tabel 3. Hasil Reliabel Menggunakan Cronbach Alpha Reliability Statistics

Cronbach's

\begin{tabular}{ll} 
Alpha & $\mathrm{N}$ of Items \\
\hline .650 & 15
\end{tabular}

Dasar pengambilan keputusan dalam uji reliabilitas sebagai berikut

1. jika nilai cronbach alpha $>0,60=$ reliabel atau konsisten

2. jika nilai cronbach alpha $<0,60=$ tidak reliabel atau tidak konsisten

Kita lihat dari tabel 3 hasil reliabel yang dilakukan oleh peneliti menggunakan cronbach alpha, dapat di peroleh hasil cornbach alpha $=0,65$ maka dapat disimpulkan bahwa uji reliabilitas yang peneliti lakukan tentunya reliabel (konsisten) karena lebih besar dari 0,60 .

\section{Uji Regresi Linier}

Tabel 4. Hasil Regresi Linier Sederhana Menggunakan SPSS

\begin{tabular}{llccllll}
\hline \multicolumn{7}{c}{ ANOVA $^{\text {a }}$} \\
\hline Model & & Sum of Squares & df & Mean Square & F & Sig. \\
\hline 1 & Regression & 8.852 & 1 & 8.852 & 3.798 & $.066^{\text {b }}$ \\
\hline
\end{tabular}




\begin{tabular}{llll}
\hline Residual & 44.290 & 19 & 2.331 \\
\hline Total & 53.143 & 20 & \\
\hline
\end{tabular}

a. Dependent Variable: DISTRIBUSI

b. Predictors: (Constant), EKSPEDISI

Pengambilan keputusan dalam uji regresi sederhana dapat dilakukan dengan 2 cara, diantaranya adalah dengan membandingkan nilai t hitung dengan t tabel, atau dengan membandingkan nilai signifikansi dengan nilai probabilitas 0,05 .

1. Jika $t$ hitung $>t$ tabel (variabel bebas berpengaruh terhadap variabel terikat).

2. Jika t hitung < t tabel (variabel bebas tidak berpengaruh terhadap variabel terikat)

Jika dilihat dari signifikansi dengan probabilitas 0,05 , yaitu :

1. Jika nilai signifikansi $<0,05$ (variabel bebas berpengaruh secara signifikan terhadap variabel terikat).

2. Jika nilai signifikansi > 0,05 (variabel bebas tidak berpengaruh secara signifikan terhadap variabel terikat).

Berdasarkan hasil uji regresi pada tabel 4 di atas dapat disimpulkan bahwa nilai sign 0,06 > 0,05, maka dapat disimpulkan variable bebas (ekspedisi) tidak berpengaruh secara signifikansi terhadap variable terikat (distribusi).

\section{Uji Korelasi}

Tabel 5. Hasil Korelasi Antara Ekspedisi Dan Distribusi Menggunakan SPSS Correlations

\begin{tabular}{llll}
\hline EKSPEDISI & & EKSPEDISI DISTRIBUSI \\
\cline { 2 - 4 } & Pearson Correlation & 1 & .408 \\
\cline { 2 - 4 } & Sig. (2-tailed) & & .066 \\
\cline { 2 - 4 } DISTRIBUSI & Pearson Correlation & .408 & 21 \\
\cline { 2 - 4 } & Sig. (2-tailed) & .066 & 1 \\
\cline { 2 - 4 } & $\mathrm{N}$ & 21 & 21 \\
\hline
\end{tabular}

Dapat dilihat pada tabel 5 bahwa hasil uji regresi pada tabel 5 dapat diketahui bahwa hubungan antara variable $\mathrm{X}$ dan $\mathrm{Y}$ memiliki hubungan yang positif, dilihat dari Pearson Correlation yang tidak tersapat minus di depannya, mengartikan bahwa hubungan variable $\mathrm{X}$ dan $\mathrm{Y}$ memiliki hubungan yang positif.

\section{B. Pembahasan}

Rekam medis ialah sebuah berkas yang berisikan catatan tentang identitas pasien, diagnosa penyakit pasien, hasil pemeriksaan, pengobatan serta tindakan dan pelayanan yang telah diberikan terhadap pasien. Rekam medis juga digunakan dalam jangka waktu panjang, supaya jika pasien tersebut berobat kembali tidak perlu membuat berkas baru, karena dokter ataupun petugas kesehatan lainnya pasti membutuhkan riwayat kesehatan terdahulu pasien tersebut, maka dari itu rekam medis sering dipinjam oleh beberapa petugas rekam medis ataupun petugas kesehatan lainnya.

Meminjam rekam medis pun tidak boleh sembarangan meminjam/mengambil, setiap rumah sakit pasti memiliki system atau SOP nya masing-masing dapat berupa buku yang disebut buku ekspedisi peminjaman maupun sudah berbasis computer SIMRS. Di rumah sakit khusus ibu dan anak, untuk peminjaman rekam medis pasien sudah berbasis computer berupa SIMRS, yang sudah satu server dengan jaringan komputer lainnya, jadi pada saat PMIK akan meminjam berkas pasien PMIK tinggal mengisi ekspedisi yang sudah terdapat di SIMRS dengan data yang sudah tersedia meliputi, nama peminjam, no rekam 
medis yang di pinjam, serta ruangan yang meminjam berkas tersebut. Dengan demikian petugas yang lain pada saat akan meminjam berkas yang sama, petugas dapat melihat berkas tersebut ada dimana dan siapa peminjamnya.

Berkas tersebut akan beralih peminjam atau di pinjam sebelum dikembalikan, maka peminjam selanjutnya harus mengisi ekspedisi sesuai dengan namanya, jika petugas yang meminjam tidak mengisi ekspedisi, itu dapat menghambat pekerjaan petugas yang lainnya contohnya petugas distribusi.

Distribusi/pendistribusian ialah proses pengiriman berkas pasien baik rawat jalan maupun inap dari bagian penyimpanan berkas menuju tempat poliklinik maupun ruangan rawat inap, di rumah sakit khusus ibu dan anak pengantaran berkas pasien masih dilakukan secara manual yaitu dengan cara menelpon dari poliklinik maupun inap kebagian distribusi, kemudian petugas distribusi akan mencari di ekspedisi SIMRS berkas tersebut ada dimana, tetapi terkadang petugas peminjam lupa akan mengisi ekspedisi peminjaman, dengan demikian hal itu dapat menghambat kinerja petugas distribusi untuk mengantarkan berkas yang di minta dan menghambat juga terhadap pelayanan pasien. Karena petugas pelayanan menghargai waktu, terkadang petugas pelayanan membuat rekam medis baru, dan itu membuat dokter atau perawat tidak dapat melihat riwayat kesehatan pasien yang sebelumya dan di penyimpanan akan menjadi double medrek.

Penulis akan membahas tentang pengaruh pengisian ekspedisi guna menunjang proses pendistribusian rekam medis, dari penelitian yang telah dilakukan menggunakan metode pendekatan kuantitatif, statistic SPSS.

Hasil penelitian yang telah dilakukan oleh penulis yaitu :

\section{Uji Validitas}

Validitas adalah suatu ukuran yang menunjukkan kevalidan atau kesahihan suatu instrument. Jadi pengujian validitas itu mengacu pada sejauh mana suatu instrument dalam menjalankan fungsi. Menurut (Azwar, 2000), validitas adalah sejauh mana ketepatan dan kecermatan suatu alat ukur dalam melakukan fungsinya.

Uji validitas yang dilkukan oleh peneliti menggunakan uji validitas data dengan rumus pearson SPSS ialah sebuah penelitian kuantitaitf yang menggunakan teknik pengumpulan data dengan angket (kuesioner). Tujuan secara umum ialah untuk mengetahui apakah angket yang digunakan benar valid atau tidak untuk di teliti.

Dasar prngambilan uji validitas, dengan perbandingan $r$ hitung dan $r$ tabel :

1. Jika nilai $r$ hitung $>r$ tabel $=$ valid

2. Jika nilai $r$ hitung $<\mathrm{r}$ tabel $=$ tidak valid

Dapat dilihat pada tabel 1 hasil uji validitas yang telah dilakukan oleh peneliti, dari tabael tersebut peneliti memberikan pertanyaan/pernyataan sebanyak 15 butir kepada 21 responden, dengan hasil > dari 0,433, maka dari itu hasil uji validitas yang dilakukan peneliti menggunakan $r$ hitung dan $r$ tabel disimpulkan valid.

Jika melihat nilai signifikansi (sign) :

1. Jika nilai signifikansi $<0,05=$ valid

2. Jika nilai signifikansi $>0,05=$ tidak valid

Tabel 2 hasil uji validitas menggunakan signifikansi yang dilakukan oleh peneliti dengan 15 butir pertanyaan/pernyataan yang di berika kepada 21 responden, dengan hasil $<0,05$, maka dari itu hasil uji validitas menggunakan signifikansi yang dilakukan oleh peneliti dapat disimpulkan valid.

\section{Uji Reliable}

Uji reliabilitas merupakan alat yang digunakan untuk mengukur konsistensi kuesioner yang merupakan indikator dari variabel atau konstruk. Suatu kuesioner dikatakan reliabel atau handal jika jawaban seseorang terhadap pertanyaan adalah konsisten atau stabil dari waktu ke waktu (Ghozali, 2006). 
Buku (V. Wiratna Sujarweni. 2014. SPSS untuk penelitian. Yogyakarta: pustaka baru press. Hal - 193) menjelaskan bahwa uji reliabilitas dapat dilakukan secara bersamasama terhadap seluruh butir atau item pertanyaan dalam angket (kuisioner) penelitian. Adapun dasar pengambilan keputusan dalam uji reliabilitas sebagai berikut:

1. jika nilai cronbach alpha $>0,60=$ reliable atau konsisten

2. jika nilai cronbach alpha $<0,60=$ tidak reliable atau tidak konsisten

Kita lihat dari tabel 3 hasil reliable yang dilakukan oleh peneliti menggunakan cronbach alpha, dapat di peroleh hasil cornbach alpha $=0,65$ maka dapat disimpulkan bahwa uji reliable yang peneliti lakukan tentunya reliable (konsisten) karena lebih besar dari 0,60 .

\section{Uji Regresi Linier}

Menurut (Sugiyono, 2017) analisis regresi adalah untuk membuat keputusan apakah naik dan menurunnya variabel dependent dapat dilakukan melalui peningkatan variabel independent atau tidak. Regresi sederhana didasarkan pada hubungan fungsional ataupun kausal satu variabel independent dengan variabel dependent. Analisis regresi ini digunakan untuk memprediksi seberapa jauh perubahan nilai variabel dependent, bila variabel independent dimanipulasi atau dirubah-rubah atau dinaik-turunkan.

Pengambilan keputusan dalam uji regresi sederhana dapat dilakukan dengan 2 cara, diantaranya adalah dengan membandingkan nilai t hitung dengan $t$ tabel, atau dengan membandingkan nilai signifikansi dengan nilai probabilitas 0,05 .

1. Jika thitung $>t$ tabel (variabel bebas berpengaruh terhadap variabel terikat).

2. Jika thitung $<\mathrm{t}$ tabel (variabel bebas tidak berpengaruh terhadap variabel terikat).

Jika dilihat dari signifikansi dengan probabilitas 0,05 , yaitu :

1. Jika nilai signifikansi $<0,05$ (variabel bebas berpengaruh secara signifikan terhadap variabel terikat).

2. Jika nilai signifikansi > 0,05 (variabel bebas tidak berpengaruh secara signifikan terhadap variabel terikat).

Hasil uji regresi pada tabel 4 diatas dapat disimpulkan bahwa nilai sign $0,06>0,05$, maka dapat disimpulkan variable bebas (ekspedisi) tidak berpengaruh secara signifikansi terhadap variable terikat (distribusi).

\section{Uji Korelasi}

Menurut (Susanto, 2014), analisis korelasi adalah sekumpulan teknik untuk mengukur hubungan antara dua variabel, gagasan dasar dari analisis korelasi adalah melaporkan hubungan antara dua variabel. Variabel X ( garos horizontal dalam grafik) dan variabel Y (garis vertikal dalam grafik) dapat menjadi hubungan non-linear, positif atau negatif. Dapat dilihat pada tabel 5 bahwa hasil uji regresi pada tabel 5 dapat diketahui bahwa hubungan antara variable $\mathrm{X}$ dan $\mathrm{Y}$ memiliki hubungan yang positif, dilihat dari Pearson Correlation yang tidak tersapat minus di depannya, mengartikan bahwa hubungan variable $\mathrm{X}$ dan $\mathrm{Y}$ memiliki hubungan yang positif.

\section{KESIMPULAN}

Berdasarkan hasil dan pembahasan penelitian yang dilakukan mengenai pengaruh pengisian ekspedisi guna menunjang efisiensi pendistribusian rekam medis rawat jalan di rumah sakit khusus ibu dan anak bandung, dapat disimpulkan bahwa setiap pernyataan/pertanyaan yang terdapat pada kuisioner/angket di uji validitas menggunakan SPSS 17.0 dinyatakan valid begitupun dengan reliabilitas atau kekonsistenan, tetapi pada saat diujikan regresi ternyata dapat dihasilkan hubungan antara variable $X$ (ekspedisi) dan variable $\mathrm{Y}$ (distribusi) tidak berpengaruh namun memiliki hubungan yang positif. 


\section{BILIOGRAFI}

Arif, M. R. (2018). Pengelolaan Arsip Rekam Medis di Rumah Sakit Aminah Tangerang. Jakarta: Fakultas Adab \& Humaniora UIN Syarif Hidayatullah.

Azwar, S. (2000). Reliabilitas dan Validitas, Yogyakarta: Pustaka Belajar. 2010. Metode Penelitian. Yogyakarta: Pustaka Belajar.

Ghozali, I. (2006). Aplikasi analisis multivariate dengan program SPSS. Badan Penerbit Universitas Diponegoro.

Jamil, N. M., Muna, N., Wijayanti, R. A., \& Wicaksono, A. P. (2020). Sistem Informasi Peminjaman Dan Pengembalian Dokumen Rekam Medis Menggunakan Metode Waterfall (Studi Kasus Puskesmas Banjarsengon). J-REMI: Jurnal Rekam Medik Dan Informasi Kesehatan, 1(2), 94-103.

Menkes, R. I. (2010). Peraturan Menteri Kesehatan Republik Indonesia Nomor 340/Menkes. Per/III/2010 Tentang Klasifikasi Rumah Sakit.

Mun, K. H., Im Yu, G., Choi, B. Y., Kim, M. K., Shin, M.-H., \& Shin, D. H. (2019). Association of dietary potassium intake with the development of chronic kidney disease and renal function in patients with mildly decreased kidney function: The Korean Multi-Rural Communities cohort study. Medical Science Monitor: International Medical Journal of Experimental and Clinical Research, 25, 1061.

Pratiwi, R. (2021). Analisis Faktor-Faktor yang Menyebabkan Keterlambatan pada Penyediaan Dokumen Rekam Medis Rawat Jalan: Literature Review. Jurnal Ilmiah Permas: Jurnal Ilmiah STIKES Kendal, 11(2), 433-446.

Putri, L., \& Putra, F. (2018). Gambaran Pendistribusian Berkas Rekam Media Poliklinik Penyakit dalam di Rumah Sakit Bhayangkara Tk. III Kota Bengkulu. Jurnal Manajemen Informasi Kesehatan (Health Information Management), 3(2).

RI, D. (2008). Keputusan Menteri Kesehatan Republik Indoneia Nomor. 129 Tahun 2009 Tentang Standar Pelayanan Minimal Rumah Sakit. Jakarta: Kemenkes RI.

RI, K. (2008). Peraturan Menteri Kesehatan nomor 129 Tahun 2008 tentang Standar Pelayanan Minimal Rumah Sakit. Jakarta. Kemenkes RI.

Salawiyah, F., Yunengsih, Y., \& Widayanti, W. (2021). Analisis Penyimpanan Rekam Medis Aktif Rawat Jalan Guna Meningkatkan Efektivitas Pelayanan Di Puskesmas Cilengkrang Kabupaten Bandung. Jurnal Inovasi Penelitian, 2(4), 1281-1286.

Sugiyono. (2013). Metode Penelitian Pendidikan Pendekatan Kuantitatif, Kualitatif, dan R\&D. In Bandung: Alfabeta.

Sugiyono, P. D. (2017). Metode Penelitian Bisnis: Pendekatan Kuantitatif, Kualitatif, Kombinasi, dan R\&D. Penerbit CV. Alfabeta: Bandung.

Susanto, I. H. (2014). TA: Rancang Bangun Aplikasi Pengolahan Data Statistik Dengan Metode Korelasi Pearson Product Moment. Stikom Surabaya.

Wati, T. G., \& Nuraini, N. (2019). Analisis Kejadian Missfile Berkas Rekam Medis Rawat Jalan di Puskesmas Bangsalsari. J-REMI: Jurnal Rekam Medik Dan Informasi Kesehatan, 1(1), 23-30.

(C) 2021 by the authors. Submitted for possible open access publication under the terms and conditions of the Creative Commons Attribution (CC BY SA) license (https://creativecommons.org/licenses/by-sa/4.0/). 